\section{ANTI-QUORUM SENSING AND ANTIBIOTIC ENHANCEMENT OF ALLYLPYROCATECHOL AND METHYL GALLATE}

Carine S. S. Lima, Eric W. C. Chana*, C. W. Wonga, Joash B. L. Tanb, V. S. Anggraenia, Z. J. Loonga, Y. K. Teob

aFaculty of Applied Sciences, UCSI University, Cheras 56000, Kuala Lumpur, Malaysia

bSchool of Science, Monash University Malaysia, Bandar Sunway 47500, Selangor, Malaysia
Article history

Received

20 September 2020

Received in revised form

17 February 2021

Accepted

16 March 2021

Published online

22 April 2021

${ }^{*}$ Corresponding author chanwc@ucsiuniversity.edu.my

\section{Graphical abstract}

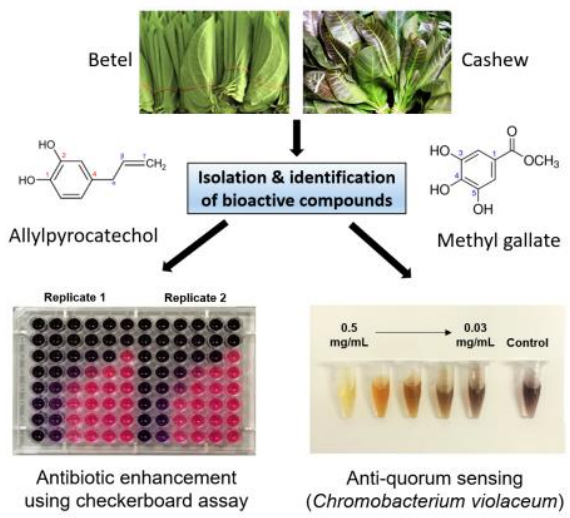

- Allylpyrocatechol (APC) and methyl gallate (MG) were isolated from betel and cashew leaves.

- The antibiotic enhancement effect of APC was additive while that of $M G$ was synergistic.

- Both compounds were equally effective with violacein inhibition observed at $60 \mu \mathrm{g} / \mathrm{mL}$.

- The purity of APC in the methanol betel leaf extract was increased from $13.2 \%$ to $31.5 \% \mathrm{w} / \mathrm{w}$ through solvent partitioning.

- This study is the first to document the anti-QS activity of APC, which is comparable to that of MG.

\begin{abstract}
In this study, the antibiotic enhancement and quorum sensing (QS) inhibition of allylpyrocatechol (APC) and methyl gallate (MG) isolated from leaves of Piper betle (betel) and leaf shoots of Anacardium occidentale (cashew), respectively, were compared. When applied with streptomycin and tested against Staphylococcus aureus and Pseudomonas aeruginosa, the effect of APC was additive while that of MG was synergistic. In terms of QS inhibition against Chromobacterium violaceum, both compounds were equally effective with violacein inhibition observed at concentrations of $60 \mu \mathrm{g} / \mathrm{mL}$. We successfully increased the purity of APC in the methanol betel leaf extract from $13.2 \%$ to $31.5 \% \mathrm{w} / \mathrm{w}$ through solvent partitioning. This study is the first to document the anti-QS activity of APC, which is comparable to that of MG.
\end{abstract}

Keywords: Allylpyrocatechol, Piper betle, methyl gallate, Anacardium occidentale, antibiotic enhancement, quorum sensing inhibition

\section{Abstrak}

Dalam kajian ini, peningkatan antibiotik dan perencatan penghindaran kuorum (QS) terhadap allylpyrocatechol (APC) dan metil gallate (MG) yang diasingkan dari daun sirih dan gajus dibandingkan. Apabila digunakan dengan streptomisin dan diuji terhadap Staphylococcus aureus dan Pseudomonas aeruginosa, kesan APC adalah aditif sementara MG bersifat sinergistik. Dari segi perencatan QS terhadap Chromobacterium violaceum, kedua sebatian tersebut sama-sama berkesan dengan perencatan violacein yang diperhatikan pada kepekatan $60 \mu \mathrm{g} / \mathrm{mL}$. Kami berjaya meningkatkan ketulenan APC dalam ekstrak daun sirih metanol dari $13.2 \%$ kepada $31.5 \% \mathrm{w} / \mathrm{W}$ melalui pembahagian pelarut. Kajian ini adalah yang pertama untuk mendokumentasikan aktiviti anti-QS APC, yang setanding dengan MG. Kata kunci: Allylpyrocatechol, Piper betle, metil gallate, Anacardium occidentale, peningkatan antibiotik, perencatan penginderaan kuorum

(c) 2021 Penerbit UTM Press. All rights reserved. 


\subsection{INTRODUCTION}

Piper betle L. (betel) is a woody vine of the family Piperaceae [1]. The heart-shaped leaves of $P$. betle are best known as a component of betel quid consisting of slices of areca nut wrapped in betel leaves with a spread over of slake lime [2]. Chewing of betel quid may be addictive but is supposed to ameliorate bad breath, harden gums, and prevent indigestion, bronchitis, constipation, congestion, cough and asthma. Pharmacological properties of $P$. betle leaves include antioxidant, antibacterial, antiquorum sensing (anti-QS), tyrosinase inhibition, antimalarial, anti-diabetic, anti-ulcerogenic antiinflammatory, hepatoprotective, neuroprotective and cytotoxic activities [2].

Anacardium occidentale L. (cashew) of the family Anacardiaceae [1]. In Southeast Asian countries of Malaysia, Indonesia and Thailand, the pliable and reddish leaf shoots of $A$. occidentale are consumed raw or blanched as ulam or traditional salad [3]. Served with hot and spicy sauce, ulam functions as an appetizer and has health-promoting properties such as antioxidant, antibacterial, antifungal, antiviral, antityrosinase, anti-ulcerogenic, analgesic, anti-inflammatory and anti-QS activities [3].

This study isolated allylpyrocatechol (APC) from leaves of $P$. betle and methyl gallate (MG) from leaf shoots of $A$. occidentale. Antibiotic enhancement and anti-QS properties of these two phenolic compounds were then compared. Finally, solvent partitioning was examined as a way of enriching the content of APC from the methanol $P$. betle extract.

Antibiotic resistance especially among Gramnegative bacteria has become a growing problem in infections [4]. Consequently, the quest for promising phytochemicals with antibiotic enhancing properties is vital. Because of the importance of QS in bacterial pathogenesis, studies have focused on QS inhibition which can result in a significant decrease in the virulence of a bacterial pathogen [5].

\subsection{METHODOLOGY}

\subsection{Extraction and Isolation}

APC was isolated from leaves of $P$. betle $(1 \mathrm{~kg})$ purchased from a local market in Kuala Lumpur. Leaves were immersed in methanol (4.5 L) and repeatedly extracted three times for $24 \mathrm{~h}$ each time. The samples were then filtered through Whatman No. 1 filter paper and the solvent was removed using a rotary evaporator under pressure at $45^{\circ} \mathrm{C}$. The extract was dissolved in minimum quantity of methanol together with same amount of packing material and oven-dried at $45^{\circ} \mathrm{C}$ for $3 \mathrm{~h}$ before loaded on the top of the packed column. All chromatographic packing materials were immersed in methanol at least $3 \mathrm{~h}$ before they were packed into their respective columns and equilibrated with the first mobile phase. The crude extract (35 g) was fractionated with $300 \mathrm{~g}$ of Diaion® HP-20, using $700 \mathrm{~mL} \mathrm{H} \mathrm{H}_{2} \mathrm{O}: \mathrm{MeOH} \mathrm{0-100 \%}$ step-gradient at $20 \%$ intervals and $100 \%$ acetone into seven fractions. Fractions 4 and 5 having the same bands from thin layer chromatography (TLC) were pooled into one fraction to designate as fractions 1-6. A bioactive compound (2 g), the major constituent of Fraction 4 (8 g), was further isolated with Sephadex LH-2O $\left(320 \mathrm{~mL}\right.$ of $\mathrm{H}_{2} \mathrm{O}: \mathrm{MeOH}$; $20-100 \%$ ) and $\mathrm{MCl}$ gel CHP2OP (80 mL of $\mathrm{H}_{2} \mathrm{O}: \mathrm{MeOH}$; $10-100 \%$ ) using step-gradient at $10 \%$ intervals and collected at $15 \mathrm{~mL}$ and $1 \mathrm{~mL}$ each, respectively, followed by $30 \mathrm{~g}$ silica gel $60160 \mathrm{~mL}$ of $\mathrm{CHCl}_{3}$ : $\mathrm{MeOH}: \mathrm{H}_{2} \mathrm{O} ; 10: 0: 0,9: 1: 0.1$ and 8:2:0.2). The eluting solvent was then removed using a rotary evaporator under pressure at $45^{\circ} \mathrm{C}$. The same spots from TLC were pooled into one fraction and the recovery yield of fractions were determined. NMR spectra were acquired using Bruker DRX-300 in deuterated chloroform (300 MHz for ${ }^{1} \mathrm{H}$ and $75 \mathrm{MHz}$ for ${ }^{13} \mathrm{C}$ ). ESI mass spectra were obtained using Agilent 1290 Infinity LC system coupled to Agilent 6520 AccurateMass Q-TOF mass spectrometer with dual ESI source.

MG was isolated from leaves of $A$. occidentale. The extraction and isolation of the compound were according to the procedures described in our previous study [6]. Briefly, the compound was dissolved in deuterated $\mathrm{MeOH}$ (CD, $\left.{ }_{3} \mathrm{OD}\right)$, and subjected to ${ }^{1} \mathrm{H}$ and ${ }^{13} \mathrm{C}$ NMR analyses using a Varian Unity Inova $500 \mathrm{MHz}$ spectrometer $\left(500 \mathrm{MHz}\right.$ for ${ }^{\mathrm{H}} \mathrm{H}$ and $125.7 \mathrm{MHz}$ for ${ }^{13} \mathrm{C}$ ). The chemical shifts were recorded in ppm (ठ). The compound was further analysed with ESI-MS using a Perkin Elmer Flexar SQ 300 quadrupole mass spectrometer to determine its molecular weight.

\subsection{Antibacterial Activity}

The minimum inhibitory concentration (MIC) was determined using the serial dilution technique and 96-well microtiter plates [7]. The samples were dissolved in $100 \%$ methanol to a concentration of 25 $\mathrm{mg} / \mathrm{mL}$ and diluted to $1 \mathrm{mg} / \mathrm{mL}$ with sterile water. Stock solution $(100 \mu \mathrm{L})$ was added to the first well and serially diluted two-fold. Diluted bacterial cultures $(90$ $\mu \mathrm{L})$ and $10 \mu \mathrm{L}$ of resazurin indicator solution (10 $\mathrm{mg} / \mathrm{mL}$ ) were then added to each well. The stock solutions of the factions were therefore subjected to final concentration of $0.5 \mathrm{mg} / \mathrm{mL}$. The subsequent $1: 2$ dilution brought the final inoculum to $5 \times 10^{7} \mathrm{CFU} / \mathrm{mL}$ [7]. Methanol (4\%) was used as the control solvent. Mueller Hinton Broth (MHB) with inoculation was used as negative control and MHB alone was prepared as blank. Plates were inoculated within $20 \mathrm{~min}$ of standardizing the inoculum to maintain viable cell density. Each sample was prepared in triplicate and the plate was incubated at $37^{\circ} \mathrm{C}$ for $18 \mathrm{~h}$ under aerobic conditions. Any change in color from blue to pink was recorded as bacterial growth.

The checkerboard assay was used to study antimicrobial synergy [8]. Stock solutions and serial 
two-fold dilutions of fraction and streptomycin to at least double the MIC were prepared. Streptomycin $(50 \mu \mathrm{L})$ was diluted along the row, while $150 \mu \mathrm{L}$ of sample was serially diluted along the column. Serially diluted samples $(50 \mu \mathrm{L})$ were then transferred into each well containing streptomycin. They were inoculated with $90 \mu \mathrm{L}$ of inoculum and $10 \mu \mathrm{L}$ of resazurin indicator solution $(10 \mathrm{mg} / \mathrm{mL})$. The plates were then incubated at $37^{\circ} \mathrm{C}$ for $18 \mathrm{~h}$ under aerobic conditions. Changes in colour from blue to pink were recorded as bacterial growth.

Antibiotic enhancement was determined by observing synergistic effects between sample and the antibiotic. Evaluation was based on the fractional inhibitory concentration (FIC) index, calculated as the MIC of streptomycin and sample combined divided by the MIC of streptomycin or sample alone. The formula used was: $\mathrm{FIC}$ index = antibiotic $\mathrm{FIC}$ (combined MIC/MIC of antibiotic) + sample FIC (combined MIC/MIC of sample). The antibacterial properties of sample were then classified according to its $\mathrm{FIC}$ i.e. synergistic $\leq 0.5$, additive $>0.5$ to $\leq 1.0$, indifferent $>1.0$ to $\leq 2.0$ and antagonistic $>2.0$ [9].

\subsection{QS Inhibition}

The violacein inhibition assay was carried out in accordance to earlier described procedures $[6,10]$. Samples were dissolved in methanol to produce stock solution of $5 \mathrm{mg} / \mathrm{mL}$. The stock solution $(0.5 \mathrm{~mL})$ was transferred into sterile petri dishes with $4.5 \mathrm{~mL}$ of nutrient broth inoculated with Chromobacterium violaceum. Optical density at $720 \mathrm{~nm}$ was $0.100 \mathrm{~A}$, which corresponded to $1.5 \times 10^{7} \mathrm{CFU} / \mathrm{mL}$. Transferring the stock solution would dilute the samples to a final concentration of $0.5 \mathrm{mg} / \mathrm{mL}$. The petri dishes were incubated for $24 \mathrm{~h}$ at $26^{\circ} \mathrm{C}$ with gentle swirling at 100 rpm before cell density was measured at OD720. A streak plate of each petri dish was done to ensure no contamination and that the optical density was a valid representation of cell density. To measure violacein production, $1 \mathrm{~mL}$ of broth culture were centrifuged at $13,000 \mathrm{rpm}$ for $15 \mathrm{~min}$ to recover the C. violaceum cells. Violacein was then extracted using $1 \mathrm{~mL}$ of butanol and centrifuged again before absorbance was measured at $577 \mathrm{~nm}$ (OD 577 ) using a blank solution of butanol. Violacein unit (VU) was expressed as the ratio of $A_{577} / A_{720}$. Violacein reduction (\%) was calculated as 100 - (VU sample/VU control $x$ 100). Lower ratio values indicate stronger $Q S$ inhibition.

\subsection{Solvent Partitioning}

Solvent partitioning of the crude extract of $P$. betle (20 g) was carried out using three different solvents (aqueous methanol, hexane and chloroform) with different polarity indices. To separate the polar compounds, the crude extract was dissolved in 400 $\mathrm{mL}$ of $90 \% \mathrm{v} / \mathrm{v}$ aqueous methanol and then in $400 \mathrm{~mL}$ of hexane using a separatory funnel. Hexane was used to separate the non-polar compounds. The funnel was shaken for 1 min before being allowed to settle for $1 \mathrm{~h}$ at room temperature. The hexane fraction was filtered through Whatman No. 1 filter paper and the solvent was removed using a rotary evaporator under pressure at $45^{\circ} \mathrm{C}$. The hexane extract was stored at $4^{\circ} \mathrm{C}$ for analysis. The lower phase which was aqueous methanol fraction was withdrawn and further partitioned using chloroform.

Chloroform and water were added into aqueous methanol fraction with 1:1:1 ratio $\mathrm{v} / \mathrm{v} / \mathrm{v}$ into a separatory funnel. The funnel was shaken for $1 \mathrm{~min}$ and allowed to settle for $1 \mathrm{~h}$ at room temperature. Both chloroform and aqueous methanol fractions were collected separately and filtered through Whatman No. 1 filter paper. The solvents were removed using a rotary evaporator under pressure at $45^{\circ} \mathrm{C}$ and stored at $4^{\circ} \mathrm{C}$ for further analysis.

\subsection{Quantification of APC}

Different solvent extracts and the pure compound were subjected to HPLC analysis. The extract was dissolved in $1 \mathrm{~mL}$ of methanol and filtered before analysis. The extract $(20 \mu \mathrm{L})$ was injected and a 40 min linear gradient from 10-100\% methanol was used to elute the sample at $1 \mathrm{~mL} / \mathrm{min}$. Mobile phases were acidified with $0.1 \%$ acetic acid to prevent ionization of analytes. Elution was monitored at three different wavelengths of 254, 280 and $365 \mathrm{~nm}$. A standard curve ranging from $0.125-1.000 \mathrm{mg} / \mathrm{mL}$ was constructed using APC from $P$. betle.

\subsection{RESULTS AND DISCUSSION}

\subsection{Structural Elucidation of Compounds}

APC (1,2-dihydroxy-4-allylbenzene) was obtained as a reddish-brown wax from $P$. betle leaves. Its identity was confirmed by analysing ${ }^{1} H$ NMR and ${ }^{13} \mathrm{C}$ NMR spectra, and by comparing with published spectral data $[11,12]$.

Its molecular formula $\mathrm{C}_{9} \mathrm{H}_{10} \mathrm{O}_{2}$ was determined by ESI-MS spectrometry that exhibited a mass of 150 with a molecular ion peak $[\mathrm{M}+\mathrm{H}]^{+}$at 151 . The molecule has two hydroxyl groups at $\mathrm{C} 1$ and $\mathrm{C} 2$ and an allyl group at C4 (Figure 1). APC or hydroxychavicol is a phenolic compound that has been reported to possess antimicrobial, antioxidant and antiinflammatory properties [13]. Other activities include anti-cancer, gastroprotective, hepatoprotective, cardioprotective and radioprotective [14].

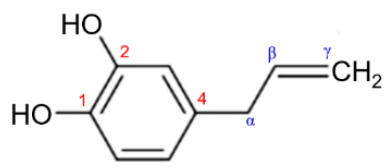<smiles>COC(=O)c1cc(O)c(O)c(O)c1</smiles>

Figure 1 Chemical structures of allylpyrocatechol (left) and methyl gallate (right) 
MG (methyl 3,4,5-trihydroxybenzoate) is a methyl ester of gallic acid. It was obtained as a white crystalline powder from $A$. occidentale leaves identified in our previous study [4]. MG with a molecular weight of 183 and molecular formula of $\mathrm{C}_{8} \mathrm{H}_{8} \mathrm{O}_{5}$ has three $-\mathrm{OH}$ groups attached to $\mathrm{C} 3, \mathrm{C} 4$ and C5 of the phenyl ring (Figure 1). A methyl carboxylic acid is attached to $\mathrm{Cl}$. MG is a phenolic compound with biological activities such as antioxidant, antityrosinase and antibacterial properties [15]. Isolated from cashew leaves, MG is a potent QS inhibitor of $C$. violaceum [4].

\subsection{Antibacterial Activity}

MIC values of APC and MG against six bacterial species ranged from 125-500 $\mu \mathrm{g} / \mathrm{mL}$. Bacillus cereus (125 $\mathrm{gg} / \mathrm{mL}$ ) was most susceptible to APC, followed by Staphylococcus aureus, Micrococcus luteus and Escherichia coli $(250 \mu \mathrm{g} / \mathrm{mL})$. The most resistant towards APC with high MIC value of $500 \mu \mathrm{g} / \mathrm{mL}$ were Pseudomonas aeruginosa and Salmonella enterica. MG was most effective against $B$. cereus 1125 $\mu \mathrm{g} / \mathrm{mL}$ ), and effective against $E$. coli and S. enterica $(250 \mu \mathrm{g} / \mathrm{mL})$. Despite the trend that most bioactive compounds from plants are more effective against Gram-positive bacteria [16], APC and MG also inhibited Gram-negative bacteria, notably, E. coli and $S$. enterica. This is an interesting finding, as these bacterial species are pathogenic and difficult to eradicate [17].

\subsection{Antimicrobial Synergy}

The FIC index of streptomycin combined with APC or $M G$ ranged from $0.38-0.75$ against $S$. aureus and $P$. aeruginosa (Table 1). A synergistic effect $(\mathrm{FI} \leq 0.5$ ) was observed when $M G$ was combined with streptomycin. Conversely, the effect of combining APC and streptomycin was only additive $(\mathrm{Fl}>0.5$ to $\leq$ 1.0). Overall, both compounds induced an increase in the activity of streptomycin with reduction in MIC values by 2 -fold to 8 -fold. Noteworthy, no indifferent $(\mathrm{Fl}>1.0$ to $\leq 2.0)$ nor antagonistic $(\mathrm{Fl}>2.0)$ interactions were observed in this study.

Table 1 Synergy between compounds and streptomycin against $S$. aureus and $P$. aeruginosa

\begin{tabular}{|c|c|c|c|c|c|}
\hline $\begin{array}{l}\text { Compd } \\
+ \text { STR }\end{array}$ & $\begin{array}{l}\text { MIC alone } \\
\text { ( } \mathrm{gg} / \mathrm{mL}) \\
\text { Compd }\end{array}$ & STR & $\begin{array}{l}\text { MIC com } \\
(\mu \mathrm{g} / \mathrm{mL}) \\
\text { Compd }\end{array}$ & $\begin{array}{l}\text { ned } \\
\text { STR }\end{array}$ & FIC \\
\hline & \multicolumn{5}{|c|}{ Staphylococcus aureus } \\
\hline $\mathrm{APC}+\mathrm{STR}$ & 250 & 62.5 & 125 & 7.81 & $0.63(A)$ \\
\hline \multirow[t]{2}{*}{$M G+S T R$} & 500 & 62.5 & 125 & 7.81 & $0.38(S)$ \\
\hline & \multicolumn{5}{|c|}{ Pseudomonas aeruginosa } \\
\hline$A P C+S T R$ & 500 & 125 & 125 & 62.5 & $0.75(A)$ \\
\hline
\end{tabular}

\begin{tabular}{llllll}
\hline $\begin{array}{l}\text { Compd } \\
+ \text { STR }\end{array}$ & $\begin{array}{l}\text { MIC alone } \\
\text { ( } \mu \mathrm{g} / \mathrm{mL}) \\
\text { Compd }\end{array}$ & STR & $\begin{array}{l}\text { MIC combined } \\
(\mu \mathrm{g} / \mathrm{mL}) \\
\text { Compd }\end{array}$ & STR & FIC \\
\hline MG + STR & 500 & 125 & 125 & 31.3 & 0.50 (S) \\
\hline
\end{tabular}

Abbreviations: $\mathrm{APC}=$ allylpyrocatechol, $\mathrm{FIC}=$ fractional inhibitory concentration, $M G=$ methyl gallate, $M I C=$ minimum inhibitory concentration and STR = streptomycin. FIC index was interpreted as $S=$ synergistic at $\leq 0.5$ and $A=$ additive at $>0.5$ to $\leq 1.0$.

A possible mode of synergistic action between compounds and antibiotics is by inducing alterations in cell membrane permeability and by inhibiting bacterial efflux pumps to increase susceptibility [18]. A study on the anticariogenic effects of the aqueous extract of $P$. betle towards Streptococcus mutans postulated that the methyl moiety of APC is responsible for the hydrophobic interaction with the lipids of the bacterial cell membrane, causing cell deformation [19]. When the bacterial cell membrane becomes more permeable, it is more susceptible to streptomycin which inhibits protein synthesis and eventually causing cell death. The synergistic interactions shown in this study suggest that both APC and MG could be useful in treating infections by drug-resistant bacteria.

\subsection{QS Inhibition}

Violacein production of $C$. violaceum in the presence of APC and MG at $10-500 \mu \mathrm{g} / \mathrm{mL}$ after $24 \mathrm{~h}$ is shown in Table 2. Results showed that at 250 and $500 \mu \mathrm{g} / \mathrm{ml}$, both compounds have a bacteriostatic effect on $C$. violaceum with very low values of cell density. Nevertheless, both compounds showed excellent anti-QS with inhibition of violacein production (> 50\%) at $60 \mu \mathrm{g} / \mathrm{mL}$. Inhibition was $55.8 \%$ and $55.2 \%$ for APC and MG, respectively.

Table 2 Violacein production of Chromobacterium violaceum based on optical density at different concentrations of allylpyrocatechol (APC) and methyl gallate (MG)

\begin{tabular}{llllll}
\hline Compd & $\begin{array}{l}\text { Conc } \\
(\boldsymbol{\mu g} / \mathrm{mL})\end{array}$ & OD $_{577}$ & OD $_{720}$ & VU & VR (\%) \\
\hline APC & 500 & 0.00 & 0.20 & 0.01 & 99.0 \\
& 250 & 0.00 & 0.10 & 0.04 & 94.8 \\
& 130 & 0.10 & 1.00 & 0.10 & 86.1 \\
& 60 & 0.44 & 1.38 & 0.32 & 55.8 \\
& 30 & 0.74 & 1.64 & 0.45 & 37.7 \\
& 10 & 0.82 & 1.66 & 0.62 & 14.7 \\
& 500 & 0.00 & 0.14 & 0.03 & 96.4 \\
& 250 & 0.00 & 0.18 & 0.02 & 96.7 \\
& 130 & 0.33 & 1.25 & 0.26 & 63.6 \\
& 60 & 0.48 & 1.47 & 0.33 & 55.2 \\
& 30 & 0.66 & 1.54 & 0.43 & 40.5 \\
\hline
\end{tabular}




\begin{tabular}{llllll}
\hline Compd & $\begin{array}{l}\text { Conc } \\
(\mu \mathrm{g} / \mathrm{mL})\end{array}$ & OD $_{577}$ & OD $_{720}$ & VU & VR (\%) \\
\hline & 10 & 0.92 & 1.63 & 0.56 & 22.5 \\
Control & & 1.10 & 1.52 & 0.73 & 0.00
\end{tabular}

Abbreviation: $O D=$ optical density at 577 and $720 \mathrm{~nm}, \mathrm{~V} U=$ violacein unit (OD577/OD720) and VR = violacein reduction. Lower ratio values indicate stronger QS inhibition.

Our study in 2015 was the first to report that MG from A. occidentale is a potent QS inhibitor [6]. They found that the closely related gallic acid did not display any anti-QS activity, suggesting that the methyl moiety in MG may be responsible for the QS inhibition. The strong anti-QS activity of MG may be attributed to the three hydroxyl groups and the methyl carboxylic acid attached to the phenyl ring as shown in Figure 1. Recently, it was reported that MG had stronger QS inhibition than phenolic compounds such as pyrogallol, pyrocatechol, resorcinol and phloroglucinol [20]. In addition, MG decreased the production of QS-regulated virulence factors in $P$. aeruginosa.

The QS inhibition of APC may also be attributed to its chemical structure and the functional groups attached. It was reported that $\beta$-keto esters are competitive antagonists of $\mathrm{N}$-acyl-homoserine lactones (AHL) and that their anti-QS activity may be attributed to the aryl functionality [21]. Pyrocatechol (APC without the allyl moiety) displayed very weak QS inhibition [20]. In this study, APC has strong anti-QS activity and is much less polar than pyrocatechol due to the allyl group.

A study on dietary phytochemicals as QS inhibitors involved mechanisms of modulation of AHL synthesis and interference of AHL activity [22]. The other mechanisms of QS disruption include reducing the activity of AHL synthase, inhibiting the production of QS signal molecules and degradation of the AHL [23]. It can be inferred that both APC and MG can inhibit the QS system either by accelerating degradation of signal molecule or reducing the ability of $C$. violaceum to synthesize signal molecules. The evidence of their mechanisms of action would require further research.

The anti-QS properties of $P$. betle leaves have been reported earlier $[24,25]$. APC has been isolated from leaves of $P$. betle [26] and has been identified as the dominant component $(39 \%)$ in the aqueous betel leaf extract [19]. However, this study is the first to document the anti-QS activity of APC, which is comparable to that of $M G$.

\subsection{Enrichment of APC}

While column chromatography is an effective method for isolating compounds, it can be very timeconsuming. Therefore, we examined solvent partitioning as a way of enriching the APC content of the methanol leaf extract of $P$. betle. Table 3 shows that the chloroform fraction had the highest APC content of $315 \mathrm{mg} / \mathrm{g}$ with purity of $31.5 \% \mathrm{w} / \mathrm{w}$ when compared to other fractions.

Table 3 Allylpyrocatechol (APC) content in different solvent fractions from the crude extract of Piper betle

\begin{tabular}{llllll}
\hline Fraction & $\begin{array}{l}\text { Fraction } \\
(\mathbf{g})\end{array}$ & $\begin{array}{l}\text { APC } \\
\text { content } \\
(\mathbf{m g} / \mathbf{g})\end{array}$ & $\begin{array}{l}\text { Purity } \\
(\% \mathrm{w} / \mathrm{w})\end{array}$ & $\begin{array}{l}\text { APC } \\
\text { yield } \\
(\mathbf{m g})\end{array}$ & $\begin{array}{l}\text { Recovery } \\
(\% \mathrm{w} / \mathrm{w})\end{array}$ \\
\hline Hexane & 3.7 & 19.6 & 2.0 & 73 & 3 \\
Chloroform & 5.1 & 315 & 31.5 & 1597 & 62 \\
Methanol & 10.6 & 84.7 & 8.5 & 898 & 35 \\
\hline Extract & 19.4 & 132 & 13.2 & 2568 & 100 \\
\hline
\end{tabular}

With regard to recovery yield, chloroform solvent recovered $62 \%$ from the crude extract and yielded $1597 \mathrm{mg}$ of APC. In contrast, the APC content, purity and recovery yield of the hexane fraction were only $19.6 \mathrm{mg} / \mathrm{g}, 2.0 \%$ and $73 \mathrm{mg}$, respectively. In spite of having the highest fraction weight of $10.6 \mathrm{~g}$, the methanol fraction yielded relatively low APC content $(84.7 \mathrm{mg} / \mathrm{g})$ and purity $(8.5 \% \mathrm{w} / \mathrm{w})$. The recovery yield of the methanol fraction $(35 \% \mathrm{w} / \mathrm{w})$ was 1.8 times lower than the chloroform fraction $(62 \% \mathrm{w} / \mathrm{w})$. The results affirm the efficiency of solvent partitioning as the purity of APC increased by 2.4 times i.e., from $13.2 \%$ in the crude extract to $31.5 \%$ in the chloroform fraction.

The basis of selection of solvents is based on their polarity. The results obtained suggest that the major phytochemicals in P. betle leaves are mostly polar and soluble in methanol. Since APC is relatively nonpolar, the highest recovery was observed in the chloroform fraction. It can be deduced that the two hydroxyl groups and one allyl group of APC contribute to the reduced polarity. Solvent partitioning into chloroform, methanol and hexane fractions is therefore a good way to enrich APC from $P$. betle leaves. Chloroform purified APC, methanol removed polar impurities and hexane removed less polar lipids.

\subsection{CONCLUSION}

Against S. aureus, $125 \mu \mathrm{g} / \mathrm{mL}$ of APC and MG, when combined with streptomycin, reduced the MIC of the antibiotic by 8 -fold. Against $P$. aeruginosa, $125 \mu \mathrm{g} / \mathrm{mL}$ of APC and MG reduced the MIC of streptomycin by 2-fold and 4-fold, respectively. In terms of QS inhibition, both compounds were shown to be equally effective against $C$. violaceum with violacein inhibition observed at concentrations as low as 60 $\mu \mathrm{g} / \mathrm{mL}$. APC and MG can breathe new life into older antibiotics such as streptomycin given their ability to reduce the MIC. Furthermore, because they exhibit anti-QS against a AHL sensitive Gram-negative 
bacteria, they could potentially reduce the virulence of C. violaceum, a Gram-negative pathogen, with a much-reduced risk of resistance. We have also successfully increased the purity of APC in the methanol $P$. betle leaf extract from $13.2 \%$ to $31.5 \%$ $\mathrm{w} / \mathrm{W}$ using simple solvent partitioning. Solvent partitioning can thus be used to expedite purification of the compound.

\section{Acknowledgement}

The authors are thankful to UCSI University for providing a research grant (REIG-FAS-2020/027) in support of this study. The laboratory facilities and technical assistance of the Faculty of Applied Sciences are acknowledged with gratitude.

\section{References}

[1] Tan, Y. P., and Chan, E. W. C. 2014. Antioxidant Antityrosinase and Antibacterial Properties of Fresh and Processed Leaves of Anacardium Occidentale and Piper Betle. Food Biosci. 6: 17-23. DOI: 10.1016/j.fbio.2014.03. 001

[2] Chan, E. W. C., and Wong, S. K. 2014. Phytochemistry and Pharmacology of Three Piper Species: An Update. Int. J. Pharmacogn. 1(9): 534-544. DOI: 10.13040/IJP.2348 3962.1 (9).534-544

[3] Chan, E. W. C., Baba, S., Chan, H. T., Kainuma, M., Inove, T., and Wong, S. K. 2017. Ulam Herbs: A Review on the Medicinal Properties of Anacardium occidentale and Barringtonia racemosa. J. Appl. Pharm. Sci. 7(2): 241-247. DOI: 10.7324/ JAPS. 2017.70235

[4] Bolla, J. M., and Brunel, J. M. 2014. Enhancing Antibiotic Activity to Combat Resistant Gram-negative Bacteria: What's Next? Future Med. Chem. 6(17): 1849-1851. DOI: $10.4155 /$ fmc. 14.128

[5] Martin, C. A., Hoven, A. D., and Cook, A. M. 2008. Therapeutic Frontiers: Preventing and Treating Infectious Diseases by Inhibiting Bacterial Quorum Sensing. Eur. J. Clin. Microbiol. Infect. Dis. 27(8): 635-642. DOI: 10.1007/s10096-008-0489-3

[6] Tan, Y. P., Chan, E. W. C., and Lim, C. S. Y. 2015. Potent Quorum Sensing Inhibition by Methyl Gallate Isolated from Leaves of Anacardium occidentale L. (cashew). Chiang Mai J. Sci. 42(3): 650-656.

[7] CLSI. 2017. Performance Standards for Antimicrobial Susceptibility Testing. In: The National Committee for Clinical Laboratory Standards Institute (CLSI), Eds. CLSI Supplement M100, 27th Ed. Wayne, PA: Clinical and Laboratory Standards Institute. 144-158.

[8] Garcia, L. S. 2007. Synergism Testing: Broth Microdilution Checkerboard and Broth Macrodilution Methods. In: Isenberg, H. D. (Ed.). Clinical Microbiology Procedures Handbook, Second Edition, Washington, DC: American Society for Microbiology.

[9] Pillai, S. K., Moellering, R. C., and Eliopoulos, G. M. 2005. Antimicrobial combinations. In: Lorian, V., (Ed.). Antibiotics in Laboratory Medicine. Fifth Edition. Philadelphia: Lippincott Williams \& Wilkins Co. 365-440.

[10] Blosser, R. S., and Gray, K. M. 2000. Extraction of Violacein from Chromobacterium violaceum Provides a $\mathrm{New}$ Quantitative Bioassay for $\mathrm{N}$-Acyl Homoserine Lactone Autoinducers. J. Microbiol. Meth. 40(1): 47-55. DOI: 10. 1016/S0167-7012(99) 00136-0.
[11] Lin, C. F., Hwang, T. L., Chien, C. C., Tu, H. Y., and Lay, H. L. 2013. A New Hydroxychavicol Dimer from the Roots of Piper Betle. Molecules. 18(3): 2563-2670. DOI: 10.3390/ molecules 18032563.

[12] Atiya, A., Sinha, B. N., and Ranjan Lal, U. 2018. New Chemical Constituents from the Piper betle Linn. (Piperaceae). Nat. Prod. Res. 32(9): 1080-1087. DOI: 10. $1080 / 14786419.2018 .1495634$

[13] Sharma, S., Khan, I. A., Ali, I., Ali, F., Kumar, M., Kumar, A., Johri, R. K., Abdullah, S. T., Bani, S., Pandey, A., and Suri, K. A. 2009. Evaluation of the Antimicrobial, Antioxidant, and Anti-inflammatory Activities of Hydroxychavicol for Its Potential Use as an Oral Care Agent. Antimicrob. Agents Chemother. 53(1): 216-222. DOI: 10.1128/AAC. 00045-08.

[14] Haslan, H., Suhaimi, F. H., Thent, Z. C., and Das, S. 2015. The Underlying Mechanism of Action for Various Medicinal Properties of Piper Betle (Betel). Clin. Therap. 166: 208-214. DOI: 10.7417/CT.2015.1880.

[15] Chaubal R., Deshpande V. H., and Deshpande N. R. 2005. Methyl Gallate, the Medicinally Important Compound: A Review. J. Environ. Agric. Food Chem. 4: 956-962.

[16] Nikaido, H. 1988. Bacterial Resistance to Antibiotics as a Function of Outer Membrane Permeability. J. Antimicrob. Chemother. 22: 17-22. DOI: 10.1093/jac/22.Supplement A.17.

[17] Gislene, G. F., Nascimento, G. G. F., Locatelli, J., Freitas, P. C., and Silva, G. L. 2000. Antibacterial Activity of Plant Extracts and Phytochemicals on Antibiotic Resistant Bacteria. Braz. J. Microbiol. 31: 247-256. DOI: 10.1590/ S1517-8382200000040 0003

[18] Langeveld, W. T., Veldhuizen, E. J., and Burt, S. A. 2014 Synergy Between Essential Oil Components and Antibiotics: A Review. Crit. Rev. Microbiol. 40(1): 76-94. DOI: 10.3109/1040841X.2013.763219.

[19] Thurairajah, N., and Rahim, Z. H. A. 2007. The Crude Aqueous Extract of Piper Betle L. and Its Antibacterial Effect Towards Streptococcus mutans. Am. J. Biochem. Biotechnol. 3(1): 10-15.

[20] Hossain, M. A., Lee, S. J., Park, N. H., Mechesso, A. F., Birhanu, B. T., Kang, J. W., Reza, M. A., Suh, J. W., and Park, S. C. 2017. Impact of Phenolic Compounds in the Acyl Homoserine Lactone-Mediated Quorum Sensing Regulatory Pathways. Sci. Rep. 7(1): 10618. DOI: 10.1038 /s41598-017-10997-5.

[21] Forschner-Dancause, S., Poulin, E., and Meschwitz, S. 2016. Quorum Sensing Inhibition and Structure-Activity Relationships of $\beta$-keto esters. Molecules. 21 (8): 971. DOI: 10.3390/molecules21080971

[22] Vattem, D. A., Mihalik, K., Crixell, S. H., and McLean, R. J. 2007. Dietary Phytochemicals as Quorum Sensing Inhibitors. Fitoterapia. 78(4): 302-310. DOI: 10.1016/j.fitote. 2007.03.009.

[23] Kalia, V. C. 2013. Quorum Sensing Inhibitors: An Overview. Biotechnol. Adv. 31(2): 224-245. DOI: 10.1016/j.biotech adv.2012.10.004

[24] Tan, L., Yin, W. F., and Chan, K. G. 2013. Piper nigrum, Piper betle and Gnetum gnemon - Natural Food Source with Anti-Quorum Sensing Properties. Sensors. 13(3): 3975-3985. DOI: 10.3390/s130303975.

[27] Datta, S., Jana, D., Maity, T. R., Samanta, A., and Banerjee, R. 2016. Piper Betle Leaf Extract Affects the Quorum Sensing and Hence Virulence of Pseudomonas Aeruginosa PAO1. 3 Biotech. 6(1): 18. DOI: 10.1007/s13 205-015-0348-8.

[26] Abdullah, N. F., and Hussain, R. M. 2015. Isolation of Allylpyrocatechol from Piper betle L. Leaves by using Highperformance Liquid Chromatography. J. Liq. Chromatogr. Relat. Technol. 38(2): 289-293. DOI: 10.1080/ 10826076.2014 .908782 